\title{
Procedure for Handling 4-H Accounts:
} Establishing and Maintaining a County 4-H Foundation ${ }^{1}$

\section{Marilyn Norman and Joy C. Jordan ${ }^{2}$ \\ Establishing and Maintaining a County 4-H Foundation}

County 4-H foundations can be established to raise funds on the county level. There are several steps to be followed when establishing a foundation to ensure correct management of the program and funds.

- Seek assistance from your County and District Extension Director and the State 4-H Office.

- Obtain copies of articles of incorporation and by-laws from other 4-H Foundations as guides.

- Involve and obtain commitments and support from the county 4-H advisory committee. This group should review the first draft of the by-laws, both for understanding and for suggested changes.

- Consult with and involve the county attorney's office (or other friendly legal counsel) in order to keep the corporation within legal bounds of Florida law.

- Select, appoint, and secure a Board of Directors. Suggestions of persons to serve on the board of directors: county commissioners, local bankers, and local business and organization representatives.
- Develop a Memorandum of Understanding between the County 4-H Program and the 4-H Foundation.

- Write the Articles of Incorporation and the by-laws.

- File for the not-for-profit charter with the Secretary of the State.

- Secure the corporate seal.

- Hold regular meetings.

- Maintain an active Board of Directors.

- Budget for program needs as defined by the County 4-H Advisory Committee. (The county foundation does not determine the county youth programs, but works in partnership with the advisory committee and the county faculty to support and expand the 4-H program.)

- Set fund-raising goals and structure to reach goals.

- Complete the IRS-990 tax return annually.

- Provide for an annual audit by a CPA or a professional accountant.

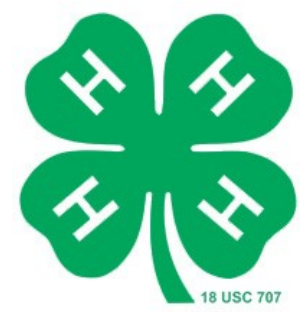




\section{Agent Responsibility with Foundations}

The county Extension agent's role in the foundation is in an ex officio capacity. No agent may serve as a member or officer. Agents should assume the responsibility of ensuring that:

- the foundation board meets regularly;

- the foundation's membership is composed of the community's top leadership;

- the foundation has built-in continuity to maintain strength and position when its leadership is weak or when agents change; and

- communication remains strong between the needs of the youth program (as determined by advisory council) and the programs for which the Foundation intends to raise funds.

\section{Maintaining an Existing 4-H Foundation}

Here are some questions that are frequently asked about how to support a quality foundation.

\section{How do I know if the Foundation is incorporated?}

If the Foundation is incorporated, copies of the original incorporation documents should be kept in a secure location in the Extension office. The Executive Officers should also have a copy. Every 4-H Foundation must complete appropriate paperwork each year with the Florida Secretary of State. The Nonprofit Corporation Annual Report must be completed and filed each year with the Florida Secretary of State. There is an annual filing fee. If the filing payment is completed and sent each year, the incorporation is up-to-date.

\section{What if I can't find any incorporation papers} and I haven't paid the fee for the current year?

If the filing of annual paperwork and fees has not been completed on a regular basis, the incorporation has lapsed. The foundation will have to apply for incorporation again.

\section{Does a county foundation have to be incorporated to accept donations?}

No. Fund-raising on the county level falls under "umbrella nonprofit" status established through the original IRS ruling of February 9,
1973. The EIN (Employer Identification

Number) should be registered with the IRS by the County Extension Office. Use this number if documentation is requested by the donor. Do not place a value on gifts of property or equipment.

\section{Then why incorporate?}

It comes down to a matter of public perception. The umbrella status is difficult for most donors to understand because there are not many organizations functioning this way. There are several thousands registered nonprofits in Florida, so most donors are used to giving money to an incorporated nonprofit.

\section{What's an EIN and why do we need one?}

The Employer Identification Number is to a nonprofit what a Social Security number is to an individual. The nonprofit needs the EIN to file Form 990 and any employee-related forms. The EIN is also needed in order to establish a bank account. When registered by the county office with the IRS, the EIN number serves as the identifier of a charity organization.

\section{Can a club in the county use the Florida 4-H Foundation's Employer Identification Number?}

No. Just as you would not allow someone else to use your Social Security number to do business, each EIN is specific to only one entity. The EIN from the county 4-H Foundation can only be used when the county 4-H Foundation serves as the fiscal agent for all 4-H clubs in the county.

\section{Do 4-H or Extension Foundations need to register with the DACS Charitable Groups list?}

The Florida Department of Agriculture and Consumer Services maintains a listing of registered groups who solicit contributions in the state of Florida

(http://www.doacs.state.fl.us/onestop/cs/solicit.h tml).

UF Legal Council has provided an answer for university-related groups such as 4-H clubs and 4-H or Extension Foundations. The DACS registration requirement does not apply to "government entities or persons or organizations who solicit...solely on their behalf." The Extension Service is surely a government entity, and since the local 4-H clubs are components of the Extension Service, they would be included under the Service's "government entity" 
umbrella. Also, since the Extension Foundations and the county 4-H foundations exist solely to solicit donations on behalf of the Extension Service and UF (also a government entity), they would be excepted from the registration requirement.

Bottom line: "Neither the local 4-H clubs, Extension Foundations, nor the county 4-H foundations are required to register with the DACS" (UF Legal Counsel, 09/07).

\section{Resources}

For additional resources, see these 4-H Fact sheets: A Guide for Extension Agents in Authorizing and Chartering 4-H Clubs and Affiliate Groups and Creating a Memorandum of Understanding with 4-H Affiliate Groups.

These fact sheets can also be obtained by going to the Florida 4-H Web site at http://www.Florida4h.org. 